\title{
32. LATE CRETACEOUS MAGNETOSTRATIGRAPHY OF SITE 516, RIO GRANDE RISE, SOUTHWESTERN ATLANTIC OCEAN, DEEP SEA DRILLING PROJECT, LEG 72 ${ }^{1}$
}

\author{
N. Hamilton, Department of Geology, University of Southampton, Southampton, United Kingdom \\ and \\ A. E. Suzyumov, P. P. Shirshov Institute of Oceanology, U.S.S.R. Academy of Sciences, Moscow, U.S.S.R.
}

\begin{abstract}
A Late Cretaceous magnetostratigraphy for the Rio Grande Rise, southwestern Atlantic Ocean, was determined from a paleomagnetic study of a thick sequence of pelagic carbonates recovered during drilling at Site 516. The observed Santonian through Maestrichtian magnetozones were satisfactorily correlated to those already established from the classic section of the Umbrian Apennines at Gubbio. There was limited evidence from Site 516 of a possible geomagnetic fluctuation immediately after the Cretaceous/Tertiary boundary event.
\end{abstract}

\section{INTRODUCTION}

Recovery of a thick sequence of pelagic carbonates from the crest of the Rio Grande Rise at Site 516 (Fig. 1) allows for a detailed investigation of the Late Cretaceous magnetostratigraphy in the southwestern Atlantic. An attempt can then be made to see if this magnetostratigraphy is correlative to that determined in other equivalent-age pelagic sequences, for instance that of the Umbrian Appenines (Alvarez et al., 1977).

Study of the magnetostratigraphy of Late Cretaceous sediments was pioneered by Keating and others (1975) with their paleomagnetic investigation of indurated chalk sequences from Lord Howe Rise (Tasman Sea) at Sites 207 and 208. Results from these sites, integrated with data from a land sequence in Mexico (the Mendez Shale), enabled a composite polarity stratigraphy to be proposed for the Maestrichtian Stage of the Late Cretaceous. Three intervals of reversed polarity were recognized. These authors suggested that the Cretaceous/Tertiary boundary penetrated at Site 208 is marked by a reversed to normal polarity transition, although they recognized that sedimentation across the boundary was discontinuous.

Subsequent work provides a more comprehensive assessment of Cretaceous magnetostratigraphy from Atlantic Ocean DSDP sediments drilled during Legs 40, 41, 43, and 44 (Keating and Helsley, 1978a). For the Late Cretaceous, these studies emphasize mixed polarities in the Maestrichtian; the underlying Campanian exhibited normal polarity throughout, except for reversals near to its upper and lower boundaries.

In the context of this present study, the mixed polarities at Site 363 are of particular relevance; Site 363 is situated on the northeastern ridge of the Walvis Rise, which is the conjugate to the Rio Grande Rise in the southeastern Atlantic (Keating and Helsley, 1978b). A well-defined normal to reversed boundary exists in fora-

\footnotetext{
${ }^{1}$ Barker, P. F., Carlson, R. L. Johnson, D. A., et al,, Init, Repts. DSDP, 72: Washington (U.S. Govt. Printing Office).
}

miniferal-nannofossil oozes and chalks of the upper Maestrichtian at this site. Biostratigraphically, this reversal boundary is located within the Micula mura nannofossil zone and within the Abathomphalus mayaroensis foraminifer zone.

Further discussion of Cretaceous magnetostratigraphy was presented by Hailwood and others (1980) after the initial phase of passive margin drilling in the eastern North Atlantic (Legs 47 and 48). Drilling on the Iberian continental margin near the Vigo Seamount (Site 398) encountered Santonian to Maestrichtian marly nannofossil chalks. Again these sediments are associated with mixed polarities, and an interval of reversed polarity characterizes the uppermost Maestrichtian.

Based on only the magnetostratigraphic record obtained from these previous DSDP studies, there were at least three intervals of reversed polarity during the Late Cretaceous, after the Cretaceous long normal polarity interval. Lack of continuous coring, incomplete core recovery, imprecise biostratigraphic control, and the generally fragmentary nature of the polarity record, based on inclination data alone, preclude a more complete appraisal of Late Cretaceous geomagnetic field behavior from these earlier DSDP investigations. To achieve this complete appraisal, recourse to pelagic limestone sequences preserved as uplifted sections on land is necessary.

Such a foundation for a detailed appraisal of Late Cretaceous magnetostratigraphy was well established by the classic studies in the Umbrian Apennines at Gubbio (Alvarez et al., 1977) and subsequently extended to include sequences in the southern Alps of northern Italy (Channell and Medizza, 1981). An up-to-date review of geomagnetic polarity changes throughout the entire Cretaceous, deduced mainly from paleomagnetic studies of pelagic carbonates and correlated with the marine magnetic anomaly record, has been given by Lowrie and others (1980).

Recovery of a Late Cretaceous-Paleocene sequence spanning the Cretaceous/Tertiary boundary at Site 384, northwestern Atlantic, prompted Larson and Opdyke 


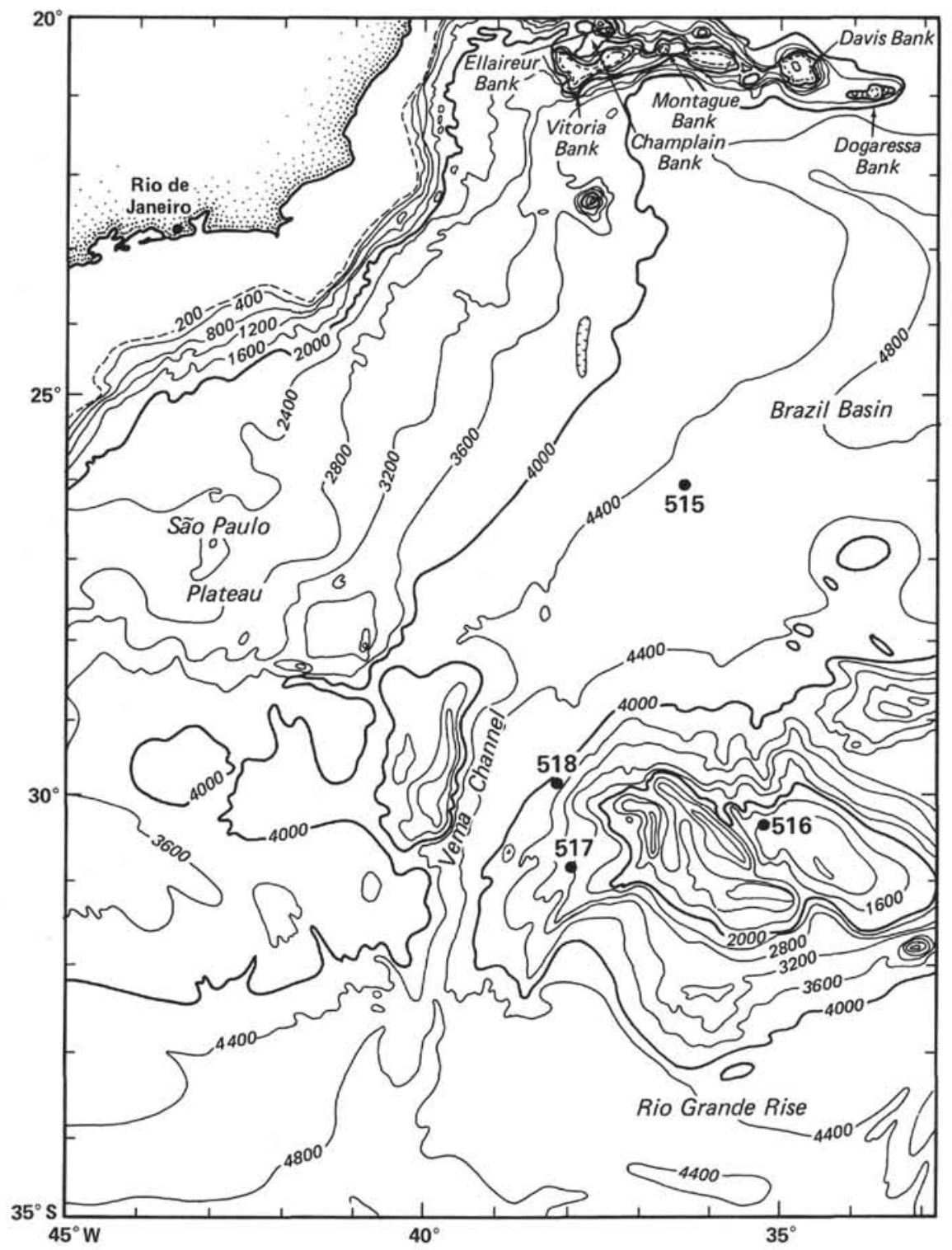

Figure 1. Location of Site 516.

(1979) to see if this sequence contained a polarity stratigraphy that could be compared directly to that proposed for Gubbio (Alvarez et al., 1977). Their interpretation for Site 384 suggests the coincidence of the base of a normal polarity zone, correlated to Anomaly 29, with the Cretaceous/Tertiary boundary. This differs from the Gubbio section, where the boundary is located in the reversed interval $\left(\mathrm{G}^{-}\right)$between Anomalies 29 and 30. Thierstein and Okada (1979) propose a modified interpretation of the magnetostratigraphy at Site 384. Essentially their reinterpretation identifies a short normal polarity interval within the $\mathrm{G}^{-}$magnetozone; the Cretaceous/Tertiary boundary is then located near the base of this interval. Such a short normal polarity interval, however, is not recorded in the Gubbio section; neither has it been recognized in the marine magnetic anomaly profiles. There is some doubt as to whether the biostratigraphically located Cretaceous/Tertiary boundary at Site 384 occurs within a hiatus.
In the light of these possible ambiguities, the more complete recovery across the Cretaceous/Tertiary boundary at the Rio Grande Rise Site 516 offers a better opportunity to compare Late Cretaceous magnetostratigraphy from a DSDP drill hole with the Italian stratotype.

\section{SAMPLING AND MEASUREMENT}

Some 180 samples were obtained for paleomagnetic study from the 289-m thick Upper Cretaceous sedimentary sequence at Site 516 on the crest of the Rio Grande Rise. The quality of core recovery was such that for this preliminary study we were able to achieve a nominal sampling density of approximately one sample from each core section throughout much of the drilled sequence. Underlying the pelagic sedimentary sequence, normally magnetized tholeiitic basaltic basement was encountered (see site chapter, Site 516, this volume). There is independent evidence from the marine magnetic anomaly patterns adjacent to the Rio Grande Rise that the youngest oceanic basement below the Site is slightly older than Anomaly 34 (Barker et al., 1981). Hence the Rio Grande Rise affords a continuous stratigraphic interval extending from the Santonian to the Danian stages of the geologic record. Magnetostratigraphic studies of the remainder of the overlying 
Cenozoic interval at Site 516 are described elsewhere (site chapter, Site 516, and Berggren et al., this volume).

Following preliminary remanence measurements on board Glomar Challenger, all samples were subjected to repeat natural remanent magnetization (NRM) measurements and shore-based demagnetization. ${ }^{2}$ Seventeen percent of the samples chosen randomly from the entire collection were measured and thermally demagnetized as part of shore-based studies by one of us (A.E.S.) in the Soviet Union. The remainder of the samples were studied in the United Kingdom.

Shore-based measurements in the UK were undertaken using both a Digico "complete results" spinner magnetometer and a 3-axis CCL cryogenic magnetometer. Most samples were demagnetized to a peak field value of $30 \mathrm{mT}$ by using either a Highmoor electronically controlled demagnetizer, or a rotating-field (AF) demagnetizer for those samples measured with the cryogenic system. For the former samples, the procedure of double-demagnetization (Hillhouse, 1977) was adopted to minimize and vectorially remove any rotational remanences (RRM) acquired during the demagnetization. The rotational remanences were in all cases less than $10 \%$ of the total remanent intensities and not likely to modify the cleaned remanence inclinations to any appreciable extent. Use of these varied measurement and demagnetization procedures generally resulted in cleaned remanence directions that were broadly similar. A typical illustration of directional change on demagnetization for samples from two Maestrichtian and Campanian cores treated in this way is presented in Figure 2. Further examples of behavior during AF demagnetization are given later.

\section{DISCUSSION}

It is apparent that these dominantly micritic and marly limestones of the Rio Grande Rise show some effect of a normal polarity overprint in the NRM inclination data. Magnetic cleaning produces a more clearly defined bimodal distribution of positive and negative inclination values (Fig. 3). The modes of these distributions are close

\footnotetext{
${ }^{2}$ The remanence results for all the samples included in this study have been archived in the Deep Sea Drilling Project's Data Bank.
}

to the axial dipole field inclination value for the latitude of Site 516 in the Late Cretaceous. On the whole, the samples are of fair to moderate magnetic stability. After demagnetization, the remanent intensities vary between 0.02 and $3 \mathrm{~mA} / \mathrm{m}$, compared to a range of $0.03-5.6$ $\mathrm{mA} / \mathrm{m}$ before.

Our interpretation of the magnetic polarity stratigraphy for the Late Cretaceous sequence deduced from the downhole cleaned inclination data is shown in Figure 4, together with the biostratigraphy. In the southern hemisphere, negative inclinations correspond to normal polarity and positive inclinations to reversed polarity. Because the drilling at Site 516 terminated in igneous basement, Figure 4 also includes, from $1253 \mathrm{~m}$ to the terminal depth, the inclination data from paleomagnetic investigations of basaltic samples (see site chapter, Site 516 , this volume).

\section{Comparison between Polarity Reversal Record of Rio Grande Rise (Site 516) and Italian Stratotypes}

A probable correlation of the polarity reversal sequence observed on the Rio Grande Rise with the established magnetostratigraphy of the Gubbio section is shown in Figure 5. This correlation is made on the basis of the common identification of the Cretaceous/Tertiary boundary in both sequences and on the assumption that the dominant normal polarities of the lowermost drilled sediments and underlying igneous basement at Site 516 correspond to the upper part of the Cretaceous long normal interval (Anomaly 34).

Table 1 gives the inferred thickness of sediment accumulation during equivalent chronostratigraphic intervals for the Rio Grande Rise (Site 516) and the Umbrian

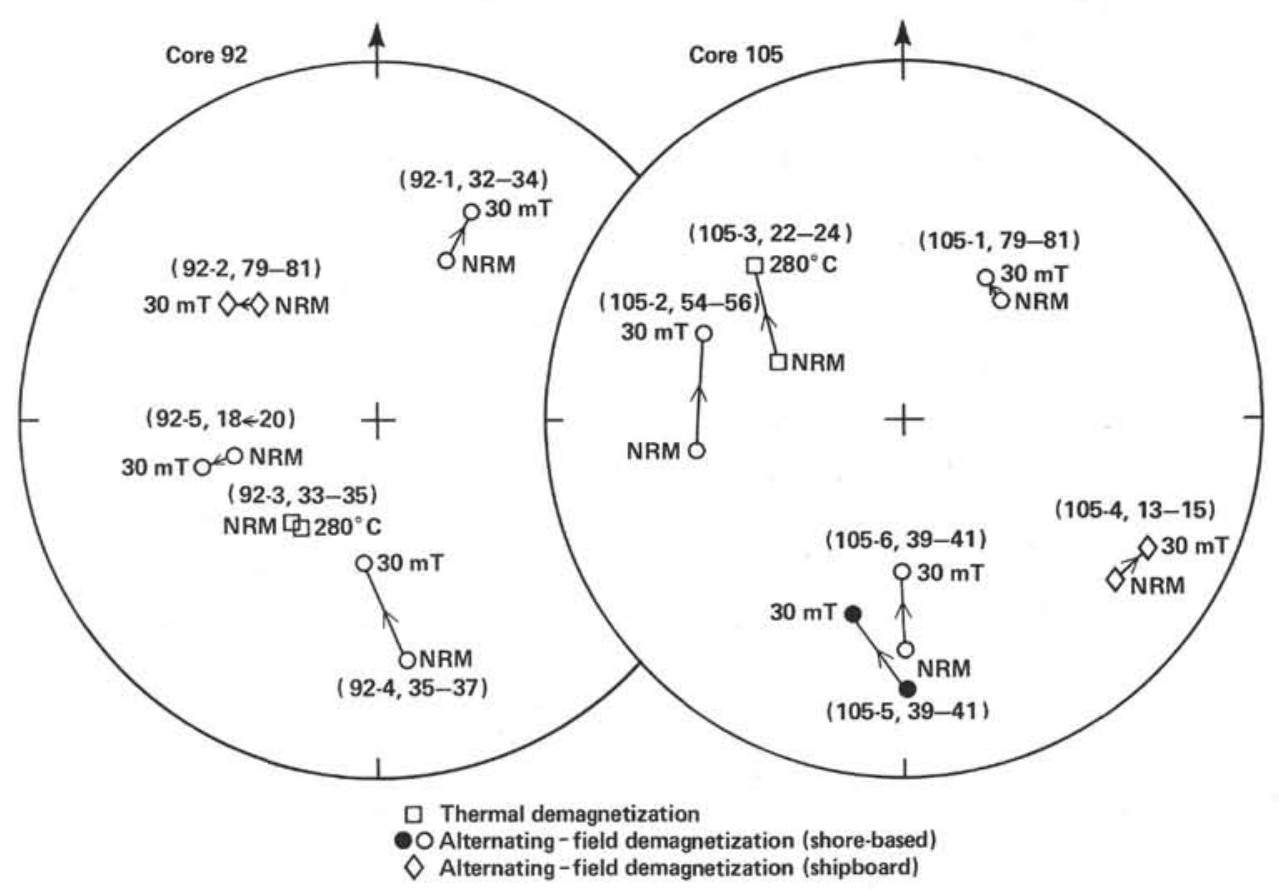

Figure 2. Examples of changes in remanence directions during magnetic cleaning of limestone samples from Hole 516F. Filled circles are positive inclinations, open circles are negative inclinations. Stereographic projection, declination reference direction is arbitrary. Numbers in parentheses indicate core-section, interval in $\mathrm{cm}$. $\mathrm{NRM}=$ natural remanent magnetization. 

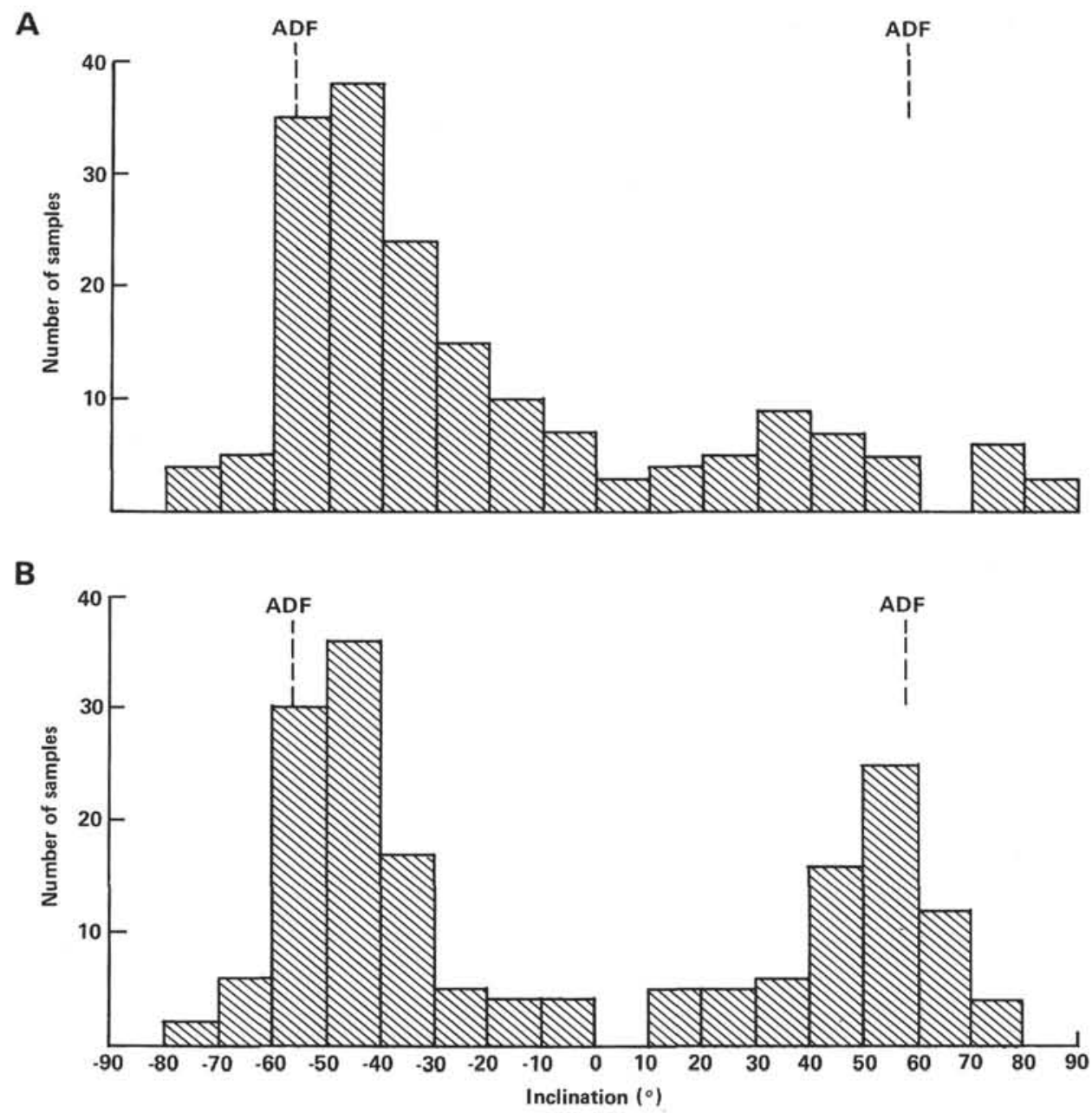

Figure 3. Histogram of inclination values: A, natural remanent magnetization (NRM) data; B, NRM data after magnetic cleaning. Dotted lines marked ADF are axial dipole field inclinations for site latitude in Upper Cretaceous.

Apennines. For completeness, data from the northwestern Atlantic, Site 384, are also included. This comparison serves to document the finer details of the variability of sedimentation rates between the widening late $\mathrm{Me}$ sozoic Atlantic Ocean and the Tethyan setting of the Umbrian Apennines, assuming that there are no undetected hiatuses in either sequence.

At Site 516, the mean overall sedimentation rate for the Campanian through Maestrichtian is $12.7 \mathrm{~m} / \mathrm{Ma}$, compared to $8.2 \mathrm{~m} / \mathrm{Ma}$ at Gubbio. These values are based on a time span of $19 \mathrm{Ma}$ for the interval from the end of Anomaly 34 (Santonian/Campanian boundary) to the beginning of Anomaly 29 (within the Danian), which was derived from the revised magnetic polarity time scale of Lowrie and Alvarez (1981). All three locations show evidence of the marked global drop in sediment accumulation rates in the early Paleocene compared to the higher rates that prevailed in the Late Cretaceous. Significant differences in sedimentation rates between Site 516 and Gubbio occur during Magnetozones $\mathrm{A}^{-}, \mathrm{D}^{+}$, and $\mathrm{F}^{+}$. Consider for example Magnetozone $\mathrm{A}^{-}$. At Site 516, some $73 \mathrm{~m}$ accumulated in this interval, compared to $22 \mathrm{~m}$ at Gubbio. If the validity of the proposed assignment of the magnetostratigraphy for the Rio Grande Rise is accepted, then it is interesting to compare the suggested biozonations. In the Umbrian Apennines and southern Alps (Alvarez et al. 1977; Channell and Medizza, 1981), Magnetozone A- occurs within the planktonic foraminiferal zone of Globotruncana elevata. Using different zonal taxa (Weiss, this volume) our interpretation suggests that the Globotruncana concavata Zone, an unnamed zone, Globotruncana arca Zone, and a portion of the Globotruncana ventricosa Zone correspond to the $\mathrm{A}^{-}$magnetozone (Fig. 4).

The provisional interpretation of polarity reversal boundaries from the cleaned inclination data at Site 516 suggests the presence of four thin normal polarity zones within $\mathrm{A}^{-}$(Fig. 4). Although the reliability of these may be questionable, the zone at $1151-1153 \mathrm{~m}$ occurs near a level at which zonal boundaries are defined for both calcareous nannofossil and planktonic foraminifers. These polarity changes may reflect magnetic excursions rather than true polarity reversals. Apparently, they were not observed in the Umbrian Apennines sequence. Nevertheless, the composite magnetostratigraphy for the Gubbio and Cismon sequences (Lowrie et al., 1980) shows an interval at the top of Magnetozone $\mathrm{A}^{-}$that has 


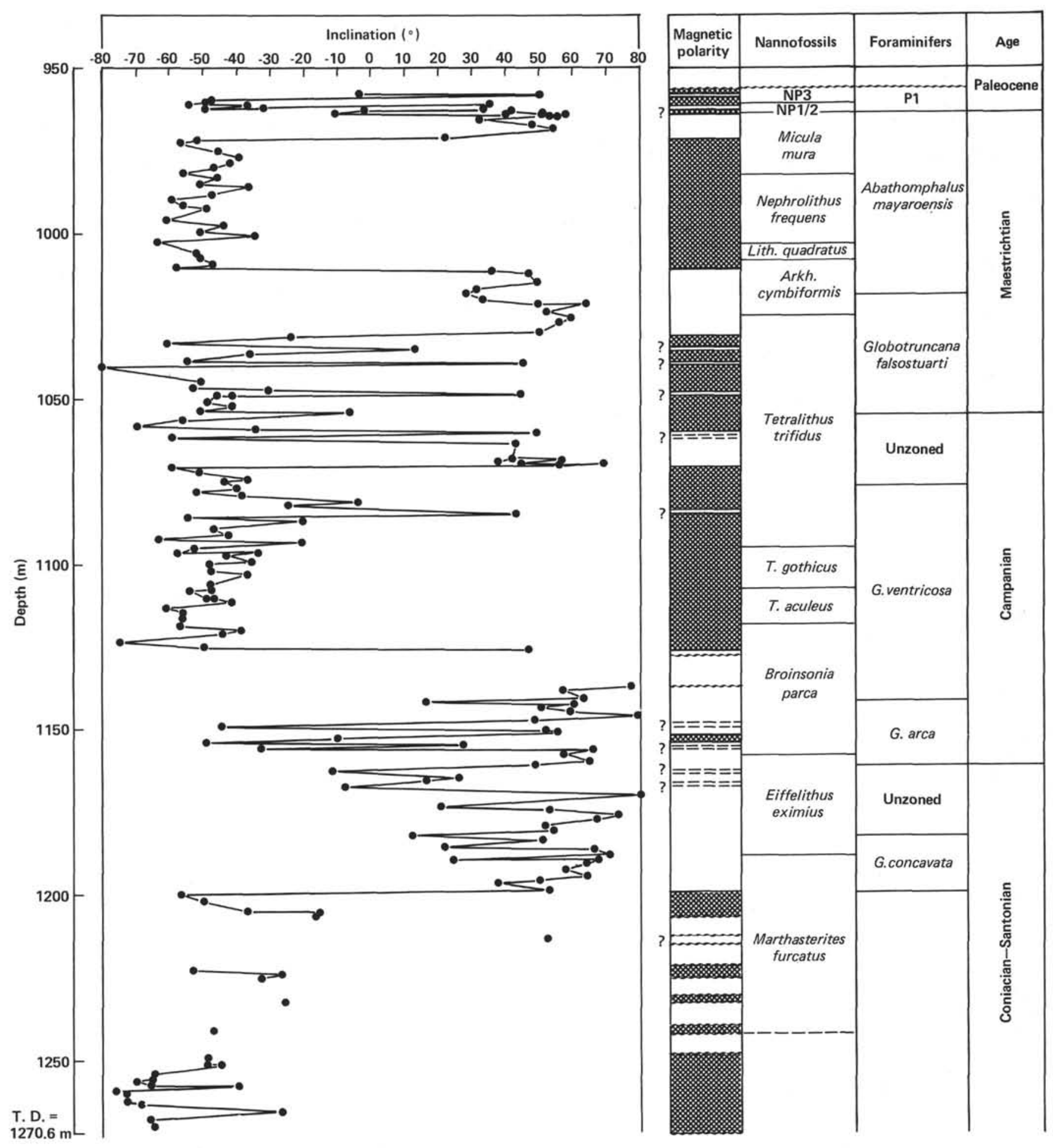

Figure 4. Downhole cleaned inclination data for Site 516 and inferred magnetic polarity shown together with biostratigraphic zonation. T. D. $=$ terminal depth; Lith. $=$ Lithraphidites: Arkh. = Arkhangelskiella.

unreliable magnetization directions and that is related, it is suggested, to tectonic deformation. This interval may be reinterpreted to indicate the existence of a short duration interval of normal polarity. On the Rio Grande Rise and at Gubbio, the postulated new normal event/ excursion occurs stratigraphically at a similar position, as judged by the relative distance above the base of the magnetozone. It will be interesting to see if any future studies substantiate this suggestion. As far as we are aware, there is no record of such an event being detected in marine magnetic anomaly profiles over oceanic lithosphere formed between Anomaly 33 and Anomaly 34 times. Nevertheless, it is not easy to resolve events of short duration or to distinguish them from geomagnetic 


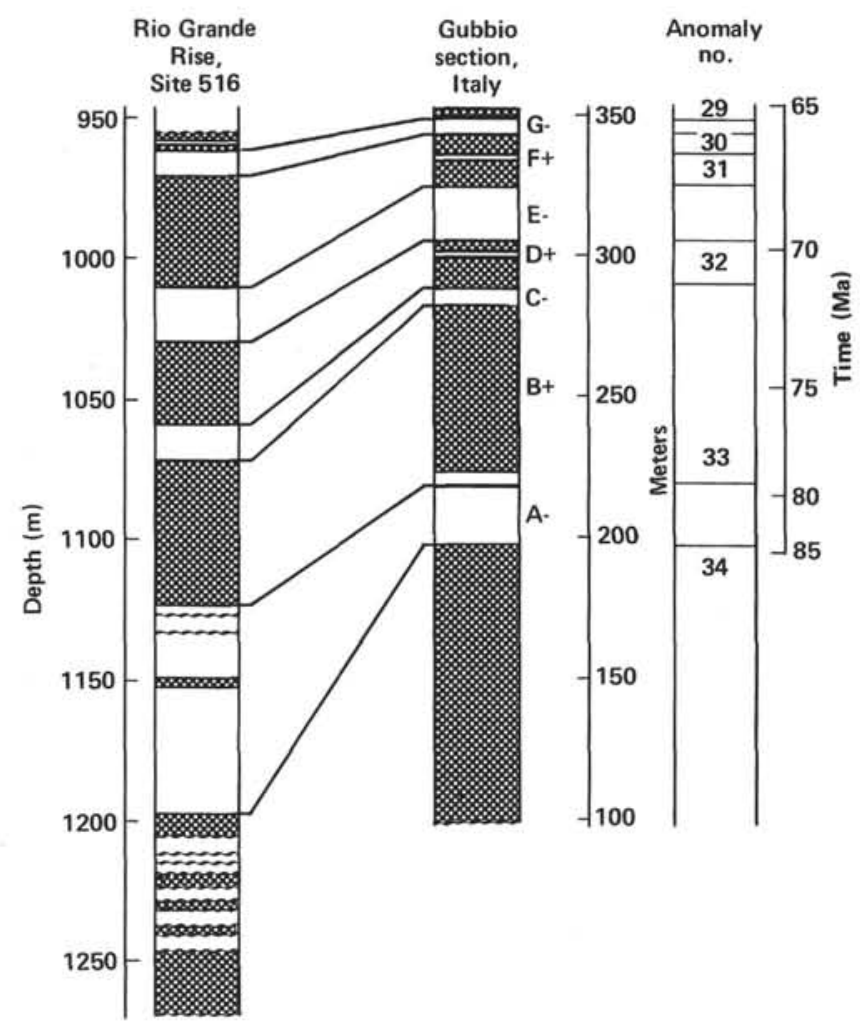

Figure 5. Proposed correlation of Late Cretaceous sequence magnetozones at Site 516 with the Gubbio section. Magnetic anomaly ages are taken from Lowrie and Alvarez (1981).

Table 1. Comparison of Late Cretaceous-early Paleocene magnetozone sediment thicknesses (in m).

\begin{tabular}{ccccl}
\hline Magnetozone & $\begin{array}{c}\text { Gubbio section } \\
\text { (Italy) }\end{array}$ & $\begin{array}{c}\text { Site 384 } \\
\text { northwestem Atlantic } \\
\text { (J Anomaly Ridge) }\end{array}$ & $\begin{array}{c}\text { Site } 516 \text { (this study) } \\
\text { southwestern Atlantic } \\
\text { (Rio Grande Rise) }\end{array}$ & Age \\
\hline I $^{-}$ & 0.5 & 1.35 & 1.0 & early \\
$\mathrm{H}^{+}$ & 2.4 & 2.8 & 3.5 & Paleocene \\
$\mathrm{G}^{-}$ & 6.0 & 3.0 & 9.0 & \\
$\mathrm{~F}^{+}$ & 18.0 & 9.5 & 39.5 & Late \\
$\mathrm{E}^{-}$ & 20.0 & & 20.0 & Cretaceous \\
$\mathrm{D}^{+}$ & 16.0 & & 29.0 & \\
$\mathrm{C}^{-}$ & 7.0 & & 11.0 & \\
$\mathrm{~B}^{+}$ & 63.0 & & 54.5 & \\
$\mathrm{~A}^{-}$ & 22.0 & & 73.0 & \\
\hline
\end{tabular}

Note: Site 384 data do not record any recovery of sediment from magnetozones older than $\mathrm{F}^{+}$

intensity fluctuations on anomaly profiles, particularly for lithosphere generated at a slow-spreading ridge (Cande and LaBrecque, 1974), as in the South Atlantic.

\section{Magnetostratigraphy Across the Cretaceous/Tertiary Boundary Sequence}

Shipboard observation that a continuous sequence across the Cretaceous/Tertiary boundary was preserved intact in Core $516 \mathrm{~F}-89$ prompted a number of interdisciplinary investigations of the "Cretaceous/Tertiary boundary event" that are reported elsewhere in this volume. Initial NRM paleomagnetic measurements made on board Glomar Challenger revealed a sharply defined transition from reversed to normal polarity coincident with the biostratigraphically determined position of the Cretaceous/Tertiary boundary. This interpretation of the magnetostratigraphy has been refined after mag- netic cleaning by AF demagnetization coupled with further resampling of the core. Because of the need to preserve for future studies this unique core, only a limited amount of resampling was approved. Nevertheless, the sampling density for the paleomagnetic study, though by no means ideal, is now for the first time sufficient to show some detail of the inclination changes close to this important chronostratigraphic boundary at a site in the southwestern Atlantic Ocean.

Reddish brown pelagic limestones form the dominant lithology of the Late Cretaceous and early Paleocene sediments of the Rio Grande Rise preserved in Core $516 \mathrm{~F}-89$. A typical response of this lithology to incremental AF demagnetization is illustrated in Figure 6. In all cases, it appears that a stable endpoint is reached after demagnetization to peak fields on the order of $15-30 \mathrm{mT}$. Figure 7 shows the downcore variation in in-
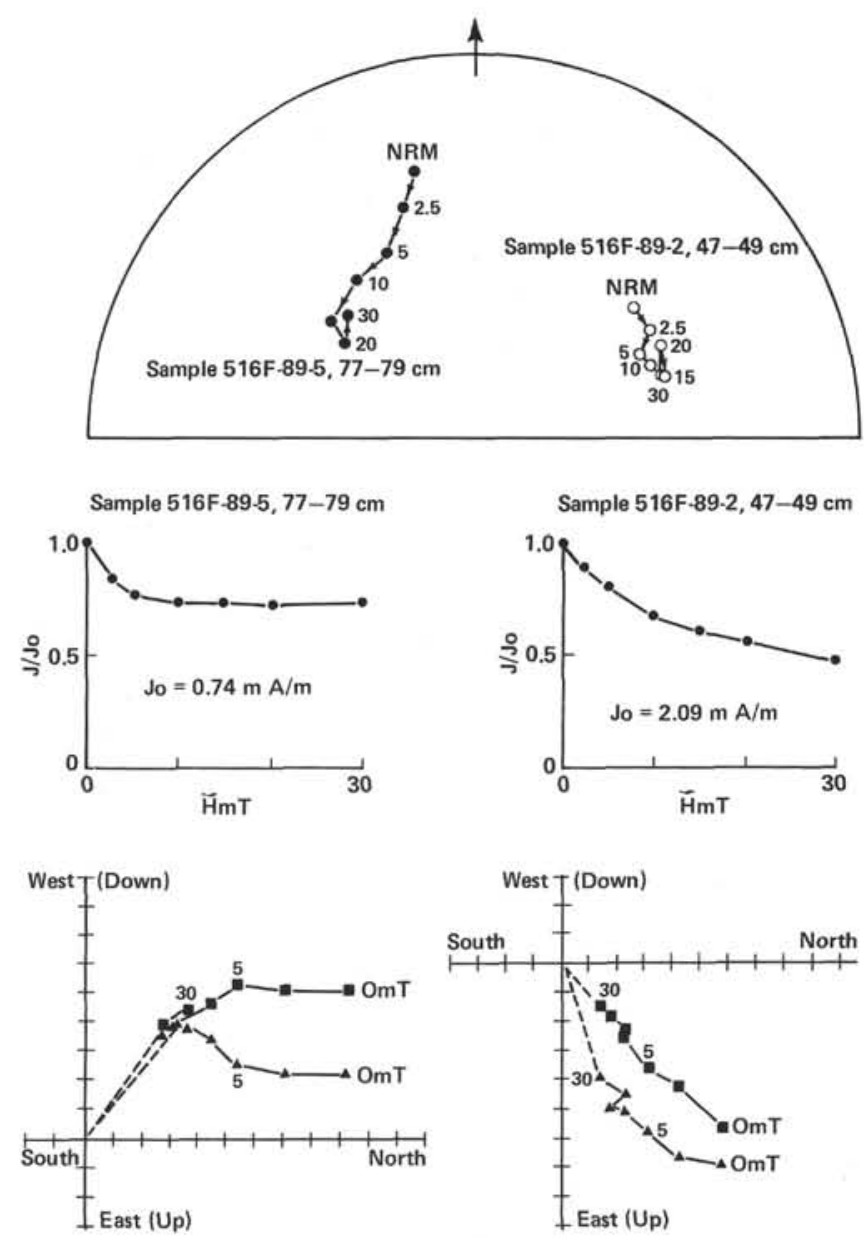

Figure 6. Typical example of progressive change in remanence direction during alternating-field demagnetization of a normal and a reversed polarity sample from Cretaceous/Tertiary boundary Core $516 \mathrm{~F}-89$. Orthogonal projection plots (Zijderveld, 1967) of the resultant magnetization vector after successive demagnetization steps are shown below the normal intensity decay curves. Squares denote projection on the vertical plane; triangles denote projection on the horizontal plane. For Sample 516F-89-5, 77-79 cm, one unit on either axis equals $0.07 \mathrm{~mA} / \mathrm{m}$, and for Sample 516F-89-2, 47-49 $\mathrm{cm}$, one unit equals $0.17 \mathrm{~mA} / \mathrm{m}$. NRM = natural remanent magnetization. 


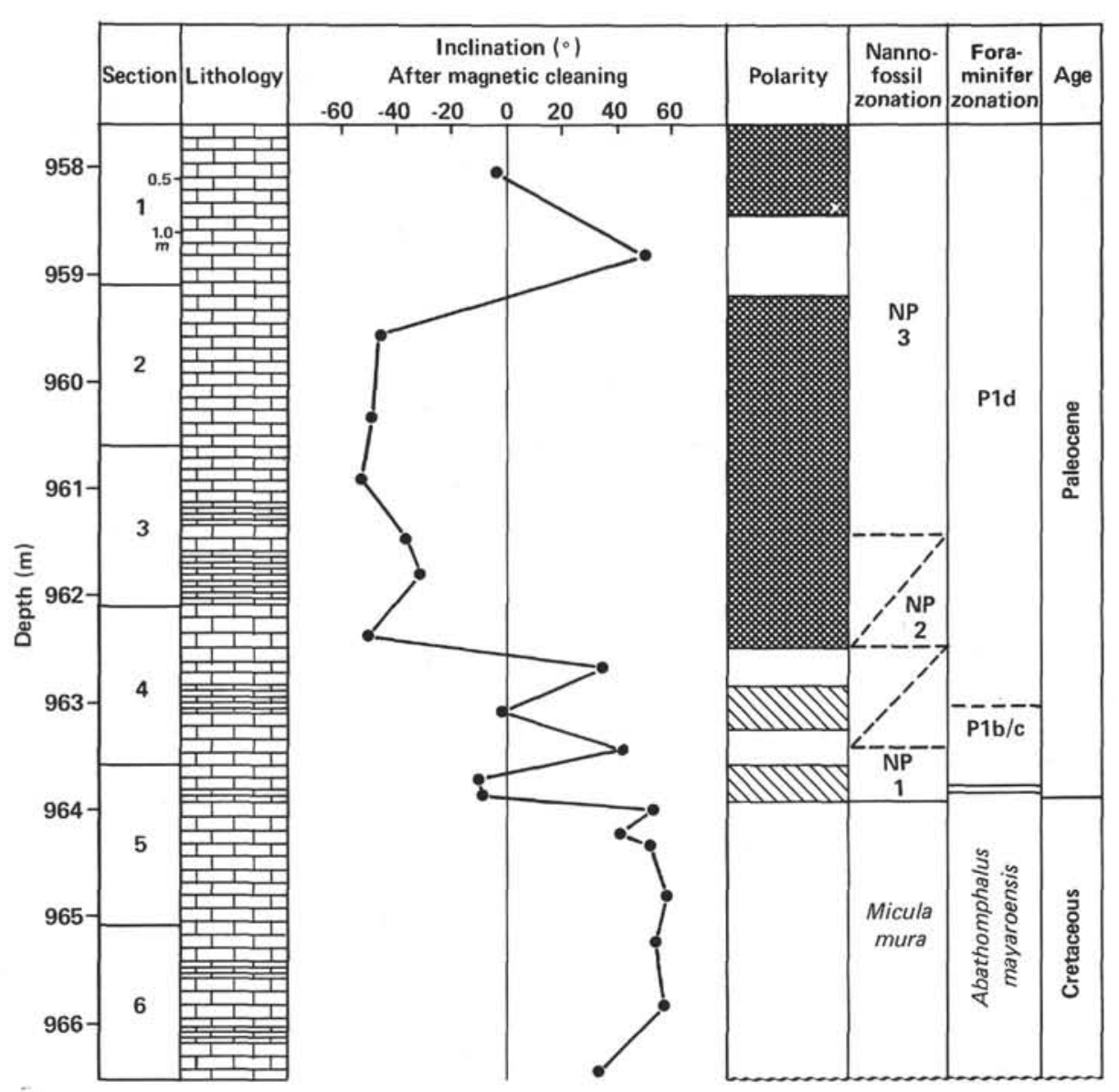

Figure 7. Inclination changes down Core $516 \mathrm{~F}-89$ adjacent to Cretaceous/Tertiary boundary after magnetic cleaning. Lined zones correspond to transitional normal polarities; black is normal polarity; and blank is reversed polarity.

clination after such magnetic cleaning at a peak field of $30 \mathrm{mT}$ for 20 samples from Core $516 \mathrm{~F}-89$, together with the biostratigraphic zonations for the core. Magnetic cleaning has partially removed a secondary normal overprint for some samples in the lowest Paleocene and reveals anomalous inclinations adjacent to the paleontologically determined Cretaceous/Tertiary boundary.

Samples within Section 516F-89-2 through the upper part of Section $516 \mathrm{~F}-89-4$, and in part of Sections $516 \mathrm{~F}-89-5$ and $516 \mathrm{~F}-89-6$, have an inclination whose modulus mean value is $46.6^{ \pm} 8.8^{\circ}$. This value is comparable to the present-day axial dipole field inclination of $49.4^{\circ}$ for the site latitude. In the early Tertiary, however, a more southerly paleoposition of the South American plate gives an axial dipole field inclination of $54^{\circ}$, by the reconstruction of Smith and Briden (1977). Slight discrepancies from the expected axial dipole field inclination value, particularly biased towards shallower inclinations, are not uncommon (see, for instance, Hamilton, 1979). On balance, the cleaned remanence inclinations of these pelagic carbonates probably do reflect a primary magnetization acquired either as a depositional or immediately postdepositional remanence. Confirmatory evidence of this assertion will require a detailed magnetomineralogic study. These details are not part of the preliminary magnetostratigraphic investigations reported here.

We can now identify the reversal boundary that occurs in Section 516F-89-4 (962.5 m sub-bottom depth) as that which defines the top of the $\mathrm{G}^{-}$Magnetozone (corresponding to the base of Anomaly 29). It is, therefore, located in the Rio Grande Rise sedimentary sequence, at Site 516, about $1.4 \mathrm{~m}$ above the Cretaceous/ Tertiary boundary and is coincident with the upper limit of the base of Zone NP2. Such a placement is identical to the assignment recognized for the Paleogene sequence of the Belluno Basin (Venetian Alps, Italy) (Channell and Medizza, 1981). It also correlates precisely with an analogous position in the Gubbio section (Alvarez et al., 1977).

There remains the question of the validity of the anomalously shallow negative inclination observed in Section 516F-89-4 and the upper part of Section 516F89-5 (Fig. 7). These inclinations are biostratigraphically located within the NP1/?NP2 nannofossil zones. We interpret these inclinations as transitional normal polarity events. The lowermost of these, occurring as it does at the Cretaceous/Tertiary boundary and spanning most of Zone NP1 is potentially the more intriguing. There is no indication that these inclination fluctuations are 
present in the Gubbio record. Therefore, whether they represent genuine fluctuation of the geomagnetic field in the earliest Danian is open to doubt. A more likely explanation is that $\mathrm{AF}$ cleaning has not entirely removed a "hard" normal overprint acquired since the earliest $\mathrm{Pa}$ leocene. Nevertheless, the evidence from DSDP Site 384 in the northwestern Atlantic does tend to support a short interval of normal polarity with its base fixed at the level of the paleontologically recognized Cretaceous/Tertiary boundary (Thierstein and Okada, 1979). Thus, there is some limited evidence emerging from DSDP studies that the exact form of the geomagnetic field behavior in the earliest Danian has not yet been fully resolved.

\section{CONCLUSIONS}

This study of the cleaned remanence inclinations of pelagic limestone samples from a 289 -m thick Late Cretaceous sequence drilled on the crest of the Rio Grande Rise enables the following conclusions to be drawn:

1) The sequence preserves a well-defined magnetostratigraphy that can be precisely correlated to the Gubbio Magnetozones $\mathrm{A}^{-}$through $\mathrm{H}^{+}$.

2) Site 516 provides, therefore, an important validation of the Gubbio magnetostratigraphy from a southern hemisphere location.

3) A previously unrecognized short normal polarity zone may be present in the upper part of the Magnetozone $\mathrm{A}^{-}$.

4) There is evidence of a geomagnetic fluctuation immediately above the Cretaceous/Tertiary boundary in the record at Site 516.

\section{ACKNOWLEDGMENTS}

We are grateful to D. Y. Spanner and G. Z. Gurary for assistance with some of the shore-based demagnetization studies. We wish also to express our thanks to Dr. E. A. Hailwood and Professor W. Lowrie for reviewing the manuscript and for the suggesting some improvements, and to Mrs. E. Diaper for typing.

\section{REFERENCES}

Alvarez, W., Arthur, M. A., Fischer, A. G., Lowrie, W., Napoleone, G., Premoli Silva, I., and Roggenthen, W. M., 1977. Upper Cretaceous-Paleocene magnetic stratigraphy at Gubbio, Italy-V-type section for the Late Cretaceous-Paleocene geomagnetic reversal time scale. Geol. Soc. Am. Bull., 88:383-389.

Barker, P. F., Carlson, R. L., Johnson, D. A., and Shipboard Scientific Party, 1981. Deep Sea Drilling Project Leg 72: Southwest Atlantic paleocirculation and Rio Grande Rise tectonics. Geol. Soc. Am. Bull., 92:294-309.

Cande, S. C., and LaBrecque, J. L., 1974. Behavior of the Earth's paleomagnetic field from small-scale marine magnetic anomalies. Nature, 247:26-28.

Channell, J. E. T., and Medizza, F., 1981. Upper Cretaceous and Paleogene magnetic stratigraphy and biostratigraphy from the Venetian (Southern) Alps. Earth Planet. Sci. Lett., 55:419-432.

Hailwood, E. A., Hamilton, N., and Morgan, G. E., 1980. Magnetic polarity dating of tectonic events at passive continental margins. Phil. Trans. R. Soc. London Ser. A, 294:189-208.

Hamilton, N., 1979. A paleomagnetic study of sediments from Site 397 northwest African continental margin, In von Rad, U., Ryan, W. B. F., et al., Init. Repts. DSDP., 47, Pt.1: Washington (U.S. Govt. Printing Office), 463-477.

Hillhouse, J. W., 1977. A method for removal of RRM. Geophys. J. R. Astron. Soc., 50:29-34.

Keating, B. H., and Helsley, C. E., 1978a. Paleomagnetic results from DSDP Hole 391C and the magnetostratigraphy of Cretaceous sediments from the Atlantic Ocean floor. In Benson, W. E., Sheridan, R. E., et al., Init. Repts. DSDP, 44: Washington (U.S. Govt. Printing Office), 523-528.

1978b. Magnetostratigraphy of Cretaceous age sediments from Sites 361, 363, 364. In Bolli, H. M., Ryan, W. B. F., et al., Init. Repts. DSDP, 40: Washington (U.S. Govt. Printing Office), 459-468.

Keating, B. H., Helsley, C. E., and Pessagno, E. A., Jr., 1975. Late Cretaceous reversal sequence. Geology, 3:73-76.

Larson, P. A., and Opdyke, N. D., 1979. Paleomagnetic results from early Tertiary/Late Cretaceous sediments of Site 384. In Tucholke, B. E., Vogt, P. R., et al., Init. Repts. DSDP, 43: Washington (U.S. Govt. Printing Office), 785-787.

Lowrie, W., and Alvarez, W., 1981. One hundred million years of geomagnetic polarity history. Geology, 9:392-397.

Lowrie, W., Channell, J. E. T., and Alvarez, W., 1980. A review of magnetic stratigraphy investigations in Cretaceous pelagic carbonate rocks. J. Geophys. Res., 85:3597-3605.

Smith, A. G., and Briden, J. C., 1977. Mesozoic and Cenozoic Paleocontinental Maps: New York (Cambridge University Press).

Thierstein, H. R., and Okada, H., 1979. The Cretaceous/Tertiary boundary event in the North Atlantic. In Tucholke, B. E., Vogt, P. R., et al., Init. Repts. DSDP, 43: Washington (U.S. Govt. Printing Office), 601-616.

Zijderveld, J. D. A., 1967. AC-demagnetization of rocks; analysis of results. In Collinson, D. W., Creer, K. M., and Runcorn, S. K. (Eds.), Methods in Palaeomagnetism: Amsterdam (Elsevier), pp. 254-286.

Date of Initial Receipt: April 8, 1982 